http://dx.doi.org/10.23891/efdyyu.2017.21

ISSN:1305-020

\title{
Fen Bilimleri Öğretmen Adaylarının Kavramsal Değişimlerine Zenginleştirilmiş Laboratuvar Rehber Materyalinin Etkisi: Buharlaşma ve Kaynama*
}

\section{Fethiye KARSLI **, Alipaşa AYAS***}

Öz: $\mathrm{Bu}$ çalışmanın amacı, 'Buharlaşma ve Kaynama' kavramlarının öğretiminde farklı kavramsal değişim yöntem/tekniklerin 5E öğretim modelinin aşamalarında kullanılması sonucu oluşturulan zenginleştirilmiş laboratuvar rehber materyalinin fen bilimleri öğretmen adaylarının kavramsal değişimine etkisini araştırmaktır. Yarı deneysel yönteme göre tasarlanan araştırmanın örneklemi, Giresun Üniversitesi’nin Fen Bilimleri Öğretmenliği Anabilim Dalı'nda öğrenim gören toplam 97 3. sınıf öğretmen adayından oluşmaktadır. Deney gruplarında bilgisayar animasyonları, kavram haritası, kavramsal değişim metni ve bilimsel süreç becerilerine dayalı deney etkinliklerinin çalışma yaprağı (ÇY) eşliğinde 5E öğretim modelinin aşamalarına entegrasyonu sonucu oluşturulan zenginleştirilmiş laboratuvar rehber materyali kullanılırken; kontrol gruplarında anlatım, soru-cevap ve kapalı uçlu deney yöntemleri kullanılmıştır. Araştırmada veri toplamak için iki aşamalı 'Buharlaşma ve Kaynama Kavram Testi (BKKT)' kullanılmıştır. BKKT'nin analizinden, deney ve kontrol grupları arasında kavramsal değişim yönünden deney gruplarının daha başarılı olduğu ortaya çıkmıştır. Yani zenginleştirilmiş laboratuvar rehber materyalinin öğretmen adaylarının 'Buharlaşma ve Kaynama' konusunda kavramsal anlamalarını daha fazla arttırdığı, dolayısıyla pozitif yönde bir kavramsal değişim sağlamasında daha etkili olduğu tespit edilmiştir.

Anahtar Kavramlar: Buharlaşma ve Kaynama, Zenginleştirilmiş Laboratuvar Rehber Materyal, Kavramsal Değiş̧im.

\footnotetext{
* Bu çalışma Fethiye KARSLI'nın doktora tezinin bir parçasıdır ve KTÜ tarafindan 2009.116.002.1 kodlu proje kapsamında desteklenmiştir.

** Giresun Üniversitesi Eğitim Fakültesi, İlköğretim Bölümü Fen Bilgisi Öğretmenliği ABD, Giresun.

***Bilkent Üniversitesi, $\quad$ Eğitim $\quad$ Fakültesi,
}

$\begin{array}{lll}\text { Gönderim:03.08.2016 } & \text { Kabul:20.02.2017 } & \text { Yayın:03.04.2017 }\end{array}$




\title{
Effect of the Enriched Laboratory Guide Material on Prospective Science Teachers' Conceptual Change: Evaporation and Boiling
}

\begin{abstract}
The aim of this study was to explore the effect of enriched laboratory guide materials, integrating different conceptual change methods/techniques according to stages of 5E model on changing prospective science teachers' alternative conceptions of "Evaporation and Boiling". A quasi-experimental method was employed. The study participants consisted of 97 prospective science teachers who studied in the science education department of Education Faculty in Giresun University. The experimental groups used the enriched laboratory guide materials, integrating different conceptual change methods or techniques such as concept map (CM), computer animations (CA), conceptual change text (CCT), worksheet and experiments based on scientific process skills according to stages of 5E model. The control groups used traditional teaching method as lecture, questions-answers and closeended experiments. To collect data, a two-tier Evaporation and Boiling Concept Questionnaire (EBCQ) were used. The results showed that the experimental groups were more successful in conceptual change than the control groups. That is, study results indicate that the learning environment designed in accordance with the enriched laboratory guide materials was more efficient than the traditional learning environment in terms of students' conceptual understanding and changing their' alternative conceptions.
\end{abstract}

Keywords: Evaporation and Boiling, Enriched Laboratory Guide Material, Conceptual Change 


\section{Giriş}

Son yıllarda kavram öğretimine yönelik çalışmaların ön plana çıkması ile birlikte fen konularında öğrencilerin var olan alternatif kavramlarının belirlenmesine ve bu alternatif kavramların giderilmesine yönelik kavramsal değişim çalışmaları da hız kazanmıştır (Duit ve Treagust, 2003; Mills, Tomas ve Lewthwaite, 2016).

Kavramsal değişim, öğrencilerin bilimsel olmayan ancak zihinlerinde yerleşmiş inanç yapısını oluşturan temel kavramlarında bilimsel olarak doğru kabul edilen bilgilere doğru köklü değişiklikler yapılması sürecidir (Anderson, 2007; Posner, Strike, Hewson ve Gertzog, 1982). Yapılandırmacı yaklaşım kavramsal değişimin sağlanmasında önemli bir yer tutmaktadır. Çünkü yapılandırmacılığın temelinde öğrencilerin yaparak ve yaşayarak var olan ön bilgilerinin üzerine doğrularının inşa edilmesi yatar. Bu süreçte de kavramsal değişim stratejileri ön plana çıkmaktadır (Hyslop-Margison ve Strobel, 2007; Treagust ve Duit, 2008). Kavramsal değişimin sağlanmasında kavramsal değişim metinleri, kavram haritaları, analojiler, animasyonlar, çalışma yaprakları gibi teknikler kullanılabilmektedir. Yapısalcı yaklaşıma, alternatif kavramlara ve farklı kavramsal değişim yöntemlerinin kullanılmasıyla oluşturulan laboratuvar ortamlarının öğrencilerin kavramsal değişimlerine (Karslı ve Ayas, 2014; Karslı ve Çalık, 2012); mantıksal ve yaratıcı düşünme becerilerine (Aktamış ve Ergin, 2007; Koray, Köksal, Özdemir ve Presley, 2007); kavramları ilişkilendirilerek anlamlandırmalarına (Karslı, 2011; Rollnick, Zwane, Staskun, Lotz ve Gren, 2001) bilimsel süreçlere ilişkin becerilerin gelişimine (Karslı ve Ayas, 2014; Karslı ve Şahin, 2009), muhakeme yeteneklerinin gelişimine ve bilimsel sorgulama yapabilmelerine (Lee, Hairston, Thames, Lawrence ve Herron, 2002) yardımcı olduğu da ifade edilmektedir. Kavramsal 
değişimin sağlanmasında öğretmenler önemli bir role sahiptir. Fen eğitiminde öğrencilere bilimsel içeriğin beklenilen düzeyde kazandırılması için, etkili bir kavram öğretiminin yapılması gerekmektedir (Coştu ve Ünal, 2005; Karsl1, 2011). Öğrencilerin fen bilimlerindeki kavramların soyut özellikler taşımasından dolayı anlamalarının zorlaştığı (Ayas ve Demirbaş, 1997; Karslı ve Ayas, 2013a), gerek günlük yaşamları (Ünal ve Coştu, 2005) gerekse öğretim sürecinde bilimsel kavramlara alternatif yapılar oluşturabilmektedirler. Literatürde bilimsel bilgilere zit olan bu kavramlar; "kavram yanılgısı" (misconception) (Nakhleh ve Krajcik, 1994), “alternatif kavramlar" (alternative conceptions) (Gonzalez, 1997), "alternatif yapılar" (alternative frameworks) (Driver ve Easley, 1978), “genel duyu kavramları” (common sense concepts) ve "kendiliğinden oluşan bilgiler" (spontaneous knowledge) (Treagust, 1988) gibi isimlerle ifade edilmektedir. Alternatif kavramlar, öğrenen kişilerin kendi fikirleri olduğu için, onlar için oldukça değerli görülmekte ve değiştirilmeye ihtiyaç duyulmamaktadır (Nieswandt, 2001). Ayrıca alternatif kavramlar değişime karşı dirençli olabildikleri için öğrencilerin daha sonraki kavramları anlamalarına olumsuz yönde etki etmektedir (Ayas, Özmen ve Çalık, 2010; Canpolat, Pınarbaşı, Bayrakçeken ve Geban, 2004). Yapılandırmacı Öğrenme Kuramı (YAÖK) yanlış ya da eksik kavramsal anlamalara sahip olan öğrencilerin kavramlarını bilimsel olanlarla değiştirmesinde oldukça etkilidir (Kayalı ve Tarhan, 2004). Çünkü YAÖK’te, öğrencilerin bilgiyi keşfetmelerine ve bilgiye kendilerinin ulaşması sonucu eski bilgileriyle yeni bilgiler arasında ilişkilendirme yaparak kavramları zihinlerinde yapılandırmaları üzerine vurgu yapılmaktadır (Carey, Evans, Honda, Jay ve Unger, 1989).

Birçok çalışmada, öğrenciler hangi sınıf seviyesi olursa olsun soyut konuların öğretilmesinin zor olduğu (Ayas ve Demirbaş, 1997; Reid, 2008; Orgill ve Bodner, 2004) ve öğrencilerin soyut özellik taşıyan konularda çeşitli alternatif kavramlar taşıdıkları ifade 
edilmektedir (Karslı ve Ayas, 2013a; Mutlu ve Acar Şeşen, 2016). Bu çalışmalar arasında,

'Buharlaşma ve Kaynama' ilköğretim, lise ve üniversite seviyesindeki öğrencilerce alternatif kavramlara sıklıkla rastlanan konulardan biri olarak değerlendirilmektedir (Finley, Stewart ve Yarroch, 1982; Osborne ve Cosgrove, 1983; Tytler , 2000).

Öğrencilerin 'Buharlaşma ve Kaynama' kavramlarında sahip oldukları alternatif kavramların literatürden tespit edilenleri Tablo 1'de liste halinde verilmiştir.

Tablo 1 .

Literatürden 'Buharlaşma ve Kaynama' kavramlart ile ilgili tespit edilen alternatif kavramlar Alternatif Kavramlar

Buharlaşma olayı su veya sulu çözeltilerle sınırlıdır. Diğer çözeltilerde ve sıvılarda buharlaşma olmaz.

Buharlaşma yüzeye bağlı bir olay değildir, sıvının her yerinde olur. $\underline{\text { Literatür }}$

$0{ }^{\circ} \mathrm{C}$ 'de buharlaşma olmaz.

Sıvı buhar dengesi kurulduğunda buharlaşma olmaz.

Buharlaşma hızı sıvının yüzey alanına bağlıdır.

Buharlaşan tanecikler çevreye 1sı verirler.

Buharlaşan madde gökyüzüne, bulutlara ya da yukarıya doğru transfer olur.

Buharlaşmanın olabilmesi için mutlaka ortamın sıcaklığının arttırılması gerekir.

Ortamın sıcaklığı sıvının sıcaklığından daha yüksek ise buharlaşma meydana gelir; yoksa buharlaşma olmaz.

Açık bir kaptaki sıvının buharlaşma hızı ile kapalı kaptaki sıvının buharlaşma hızı birbirinden farklıdır. Kapalı kapta zaman geçtikçe buharlaşma oranı azalır.

Kaynama ve buharlaşma birbiriyle ilişkilidir, eğer kaynama meydana gelmemişse,

Önce buharlaşma olur ardından kaynama gerçekleşir.

Buhar, sis, gaz ve hava aynı şeylerdir.

Buharlașma olayında su yüzeyden emilir.

Buharlaşma sıvının tümünde (her tarafında) gerçekleşir.

Çevresinden izole edilmiş kapalı bir kaptaki sıvıda buharlaşma olmaz.

Buhar basıncı kaynama süresince buhar fazındaki taneciklerin yaptığı basınçtır.

Buhar basıncı sıvının miktarına bağlıdır.

Buhar basıncı ile atmosfer basıncı aynı şeylerdir.

Buharlaşma sadece atmosferle ilgilidir, buhar basıncı ile bir ilgisi yoktur.

Suyun buharlaşması olayı bir kimyasal değişimdir.

Kaynama anında oluşan kabarcıklar içerisinde $\mathrm{H}_{2}, \mathrm{O}_{2}, \mathrm{CO}_{2}$, hava, duman ve isı vardır.

Kaynama noktası bir maddenin en yüksek sıcaklığıdır.

⿷匚 Kaynama esnasinda taneciklerin kinetik enerjisi artar.

$1,10,18-$ Su sadece $100{ }^{\circ} \mathrm{C}$ 'de kaynar.

Kaynama noktası her zaman sabittir ve değişmez.

Kaynama 1sı kaynağı tarafindan kontrol edilen bir süreçtir.

Kaynama sıvı yüzeyinde gerçekleşen bir olaydır.

Kaynama kimyasal bir değişimdir. 
Basıncın değişmesi kaynama noktasını değiştirmez. $10,20,23$

Sıvı üzerinde basıncın yükseltilmesi kaynama noktasını azaltır.

Aynı atmosfer basıncında kaynayan sıvılar farklı buhar basıncına sahiptir.

Kaynayan sıvıya ısı verildikçe, sıcaklığı artar.

Öğrenciler saf sıvıların ve çözeltilerin kaynama noktalarını ayırt edemiyorlar.

$15,24$. REÇ*: Rapor Edilen Çalışma/lar: (1) Hwang ve Hwang (1990); (2) Coştu ve Ayas (2005); (3) Canpolat (2006); (4) Goodwin (2000); (5) Chang (1999); (6) Canpolat, Pinarbasi ve Sözbilir (2006); (7) Bar ve Travis (1991); (8) Valanides (2000a); (9) Prain, Tytler ve Peterson (2009); (10) Coştu, Ayas, Niaz, Ünal ve Çalık (2007); (11) Osborne ve Cosgrove (1983); (12) Beveridge (1985); (13) Russell, Harlen ve Watt (1989); (14) Johnson (1998) (15) Bar ve Galili (1994); (16) Hatzinikita ve Koulaidis (1997); (17) Tytler (2000); (18) McElwee (1991); (19) Paik, Kim, Cho ve Park (2004); (20) Pınarbaşı ve Canpolat (2003); (21) Valanides (2000b); (22) Varelas, Pappas ve Rife (2006); (23) Coştu vd. (2003); (24) Uzuntiryaki ve Geban (2005).

Madde ve değişim ile maddenin halleri ünitelerinde yer alan "kaynama” (Hwang ve Hwang, 1990; McElwee, 1991; Paik ve diğ., 2004; Pınarbaşı ve Canpolat, 2003; Valanides, 2000a, 2000b; Varelas ve diğ., 2006), "kaynayan sıvıdaki kabarcıkların yapısı" (Chang, 1999; Goodwin, 2000; Hatzinikita ve Koulaidis, 1997; Osborne ve Cosgrove, 1983; Paik ve diğ., 2004), "kaynama, kaynama noktası ve buhar basıncını etkileyen faktörler" (Abad, 2001; Coştu, 2006; Gopal ve diğ., 2004; Pınarbaşı ve Canpolat, 2003) ve "buharlaşma, buharlaşma hızı ve buhar basıncı" (Canpolat, 2006; Canpolat ve diğ., 2006; Chang, 1999; Coştu ve Ayas, 2005; Osborne ve Cosgrove 1983; Prain, Tytler ve Peterson, 2009; Tytler, 2000) kavramlarında öğrencilerin alternatif kavramlarını belirlemeye yönelik birçok çalışma yapılmıştır. Bu çalışmaların katılımcıları ilköğretim (Bar ve Galili, 1994; Bar ve Travis, 1991; Hwang ve Hwang, 1990; Osborne ve Cosgrove, 1983; Paik ve diğ., 2004; Tytler, 2000), ortaöğretim (Osborne ve Cosgrove, 1983; Hwang ve Hwang, 1990; Andersson, 1990; Coştu ve Ayas, 2005) ve üniversite düzeyindeki öğrenciler (Hwang ve Hwang, 1990; Gopal ve diğ., 2004) ile öğretmen adaylarıdır (Chang, 1999; Pınarbaş1 ve Canpolat, 2003; Canpolat, 2006; Canpolat ve diğ., 2006). Günlük hayatımızda birebir şahit olduğumuz 'Buharlaşma ve Kaynama' kavramlarına ilişkin öğrencilerin bilimsel doğrulara ulaşmaları oldukça önemlidir. Çünkü bu kavramlar çözünme, fiziksel ve kimyasal değişimler, fiziksel özellikler, molekül içi 
ve moleküller arası bağlar gibi temel fen kavramlarıyla da ilişkilidir. Bu bağlamda 'Buharlaşma ve Kaynama' kavramlarında farklı öğrenim seviyelerindeki öğrenci ve öğretmen adaylarının sahip olduğu alternatif kavramları gidermek, onların bu kavramlarla ilişkili diğer kavramları daha iyi yapılandırabilmeleri için gereklidir. Ayrıca öğretmen adaylarının alternatif kavramlara sahip olarak öğretmenlik mesleğine başlamaları, bu alternatif kavramları kendi öğrencilerine taşıyabilecekleri düşünüldüğünde oldukça endişe vericidir (Karslı ve Çalık, 2012).

Alternatif kavramların belirlenmesi, kavramsal değişim çalışmalarının temelini oluştursa da kavramsal değişim sağlamada yeterli değildir. Bu nedenle bazı araştırmacılar 'Buharlaşma ve Kaynama' konusunda alternatif kavramları gidermek için kavramsal değişim çalışmaları yapmışlardır. Bu çalışmalardan bazıları şu şekilde özetlenebilir: Gönen ve Akgün (2005) hal değişimi konusunda Fen Bilimleri Öğretmenliği 2. sınıf öğrencileriyle çalışma yapraklarının; Coştu ve diğerleri (2007) "kaynama” kavramında Fen Bilimleri Öğretmenliği 1. sınıf öğrencileriyle kavramsal değişim yaklaşımının; Şendur, Toprak ve Pekmez (2008) 'Buharlaşma ve Kaynama' konularında lise 1. sınıf öğrencileriyle analojilerin; Papageorgiou, Johnson ve Fotiades (2008) "kaynama noktası ve buharlaşma" kavramlarında 11-12 yaş grubu öğrencileriyle simülasyonların ve Demircioğlu, Demircioğlu ve Vural (2016) "buharlaşma" kavramında üstün yetenekli öğrencilerle 5E öğretim modelininin kavramsal değişime etkilerini araştırmışlardır.

$\mathrm{Bu}$ araştırma sonuçlarında ele alınan konularda geliştirilen öğretim materyallerinin öğrencilerin olumlu yönde kavramsal değişim sağlamalarına yardımcı olduğu belirtilmektedir. 'Buharlaşma ve Kaynama' konusunda yapılan bu araştırmalarda fen bilimleri öğretmenliği 3. sınıf öğrencilerine yönelik, laboratuvar ortamında öğrencilerde olması 
muhtemel alternatif kavramlar dikkate alınarak ve $5 \mathrm{E}$ öğretim modelinin aşamalarına farklı kavram öğretim yöntem/tekniklerin entegrasyonu sonucu oluşturulan bir öğretim materyalinin etkisinin incelendiği bir araştırmaya rastlanılmamıştır. Bu araştırmada, birçok öğrencinin 'Buharlaşma ve Kaynama' kavramlarında alternatif kavramlara sahip olması ve kavramsal değişime yönelik çalı̧̧malara ihtiyaç duyulmasından yola çıkılarak bu kavramlara yönelik Bilgisayar Animasyonları (BA), Kavram Haritası (KH), Kavramsal Değişim Metni (KDM) ve deney etkinliklerinin, Çalışma Yaprağı (ÇY) eşliğinde 5E öğretim modelinin aşamalarına entegre edilerek laboratuvar ortamında kullanımı sağlanmıştır. Aslında, kavramsal anlamalarda bir gelişme her öğretim müdahalesinden sonra beklenen bir konudur. Öğrencilerin bilişsel sistemlerinde bilimsel bilgiler, alternatif kavramlar ve benzeri bilgiler var olup, bunlar birbiriyle rekabet halindedir. Bu süreçte öğretim müdahalesi öğrencilerin zihnindeki bu zorlu mücadeleden bilimsel kavramların egemen olmasını sağlayacak şekilde düzenlenirse en iyi sonuç elde edilebilir. Bu araştırmada 'Buharlaşma ve kaynama' konusunda farklı kavram öğretim yöntem ya da tekniklerle öğrenme faaliyetlerinin çeşitlendirilmesinin, mevcut öğrenme faaliyetlerine göre bu zorlu mücadeleden bilimsel kavramların ne ölçüde egemen olmasına katkı sağlayabildiği anlaşılmaya çalışılmıştır. Araştırmada farklı kavramsal değişim yöntem/tekniklerin kullanılmasıyla elde edilen sonucun hangi yöntem ya da teknikten kaynaklandığının belirlenmesi amaçlanmamış olup, bunların birbirinin eksik ve zayıf yönlerini gidererek mevcut öğretim müdahalelerine göre ne ölçüde bir fark yaratacağı anlaşılmaya çalışılmıştır. Farklı kavramsal değişim yöntem/tekniklerle zenginleştirilmiş bu materyalin fen bilimleri öğretmen adaylarının kavramsal değişimlerine etkisinin incelenmesinin ve sonuçlarının paylaşılmasının literatüre katkı sağlayacağı düşünülmektedir. Bunun yanı sıra, gelecekte öğretmen kaynaklı oluşabilecek alternatif 
kavramların oluşmasının erkenden önüne geçilebileceği düşünüldüğünden de önem arz etmektedir.

Bu çalışmanın amacı, 'Buharlaşma ve Kaynama' kavramlarında KDM, BA, KH ve deney etkinliklerinin ÇY eşliğinde 5E öğretim modelinin aşamalarına entegrasyonu sonucu oluşturulan zenginleştirilmiş laboratuvar rehber materyalinin fen bilimleri öğretmen adaylarının kavramsal değişimlerine etkisini incelemektir. Bu amaç doğrultusunda:

$\checkmark$ Fen bilimleri öğretmen adaylarının 'Buharlaşma ve Kaynama' kavramlarında ön ve son test puanları arasındaki fark anlamlı midır?

$\checkmark$ Fen bilimleri öğretmen adaylarının 'Buharlaşma ve Kaynama' kavramlarıyla ilgili geliştirilen zenginleştirilmiş laboratuvar rehber materyalinin derslerde uygulanması ile kavramsal anlamaları nasıl değişmiştir? alt problemlerine cevap aranmaktadır.

\section{Yöntem}

\section{Araştırmanın deseni}

Ön test - son test kontrol gruplu yarı deneysel yönteme göre tasarlanan araştırmanın örneklemi, Giresun Üniversite’sinin Fen Bilimleri Öğretmenliği bölümünün üçüncü sınıfında, Fen Öğretimi Laboratuvarı Uygulamaları-I dersini almış, 4 farklı şubede öğrenim gören toplam 97 öğretmen adayından (20 ile 22 yaşları arasında) oluşmaktadır. Deney ve kontrol gruplarını belirlemek için aşağıdaki prosedürler uygulanmıştır: Öğrencileri gruplara rastgele atamak mümkün olmadığı için öğrenci ve şube isimleri kağıtlara yazılarak kağıtlar kapalı bir kutuya atılmıştır. Kağıtlar karıştırılarak bir öğrenciden bu kağıtları rastgele ancak sırayla çekmesi istenmiş, seçilen ilk kağıttaki şube 1. kontrol grubunu (N=25), ikinci kağıttaki 1. deney grubunu (N=24), üçüncü kağıttaki 2. kontrol grubunu $(\mathrm{N}=24)$ ve dördüncü kağıttaki şube ise 2. deney grubunu $(\mathrm{N}=24)$ oluşturmuştur. Gönüllü olmayan ve tüm uygulamalara 
katılmayan öğrencilerin verileri araştırma sonuçlarına dahil edilmemiştir. İki farklı deney ve kontrol grubu seçilerek geliştirilen öğretim materyalinin etkisinin daha geniş bir örneklem üzerinde denenmesi sağlanmıştır.

\section{Uygulama Süreci}

İlk olarak, öğrencilere iki aşamalı Buharlaşma ve Kaynama Kavram Testi (BKKT) öğretim uygulamasından önce yaklaşık 30 dakika sürede ön test olarak uygulanmıştır. Daha sonra her gruptaki öğretmen adaylarından kendilerinin 3 ya da 4'er kişilik gruplar oluşturmaları istenmiştir. Öğretim sürecinin tamamı eğitim fakültesinin mevcut fen laboratuvarında gerçekleştirilmiştir. Öğretim uygulamaları araştırmanın ilk yazarı tarafından yaklaşık olarak 2 hafta içerisinde 8 ders saatlik (8x50 dak.) sürede tamamlanmıştır. İki aşamalı BKKT öğretim uygulamalarından sonra son test olarak ikinci kez uygulanmıştır. Deney ve kontrol grupları için iki ayrı ders planı hazırlanmıştır. Deney grupları için hazırlanan ders planı KDM, BA, KH ve bilimsel süreç becerilerine dayalı deney etkinliklerinin ÇY eşliğinde 5E öğretim modelinin aşamalarına entegrasyonu sonucu oluşturulan zenginleştirilmiş laboratuvar rehber materyalinin kullanımını içermektedir. Kontrol gruplarındaki ders planları ise anlatım, soru-cevap ve kapalı uçlu deney yöntemlerinin kullanımını içermektedir. Tablo 2'de deney gruplarında kullanılan zenginleştirilmiş laboratuvar rehber materyalinde 5E öğretim modelinin aşamalarına KDM, BA, KH ve deney etkinliklerinin ÇY eşliğinde nasıl entegre edildiği sunulmuştur.

Tablo 2

'Buharlaşma ve Kaynama' Kavramlarının Öğretiminde Kullanılan Öğretim Materyallerinin 5E Ö̆̆retim Modelinin Hangi Aşamalarında Kullanıldığı

\begin{tabular}{llll}
\hline $\begin{array}{l}\text { Öğretim } \\
\text { Materyalleri }\end{array}$ & Kullanım Amaçları & $\begin{array}{l}\text { 5E'nin } \\
\text { aşamaları }\end{array}$ \\
\hline KDM, BA, KH & ve & Öğretim sürecinde yapılacak etkinliklerin planlı ve sıralı bir şekilde & $1-5$ \\
\hline
\end{tabular}




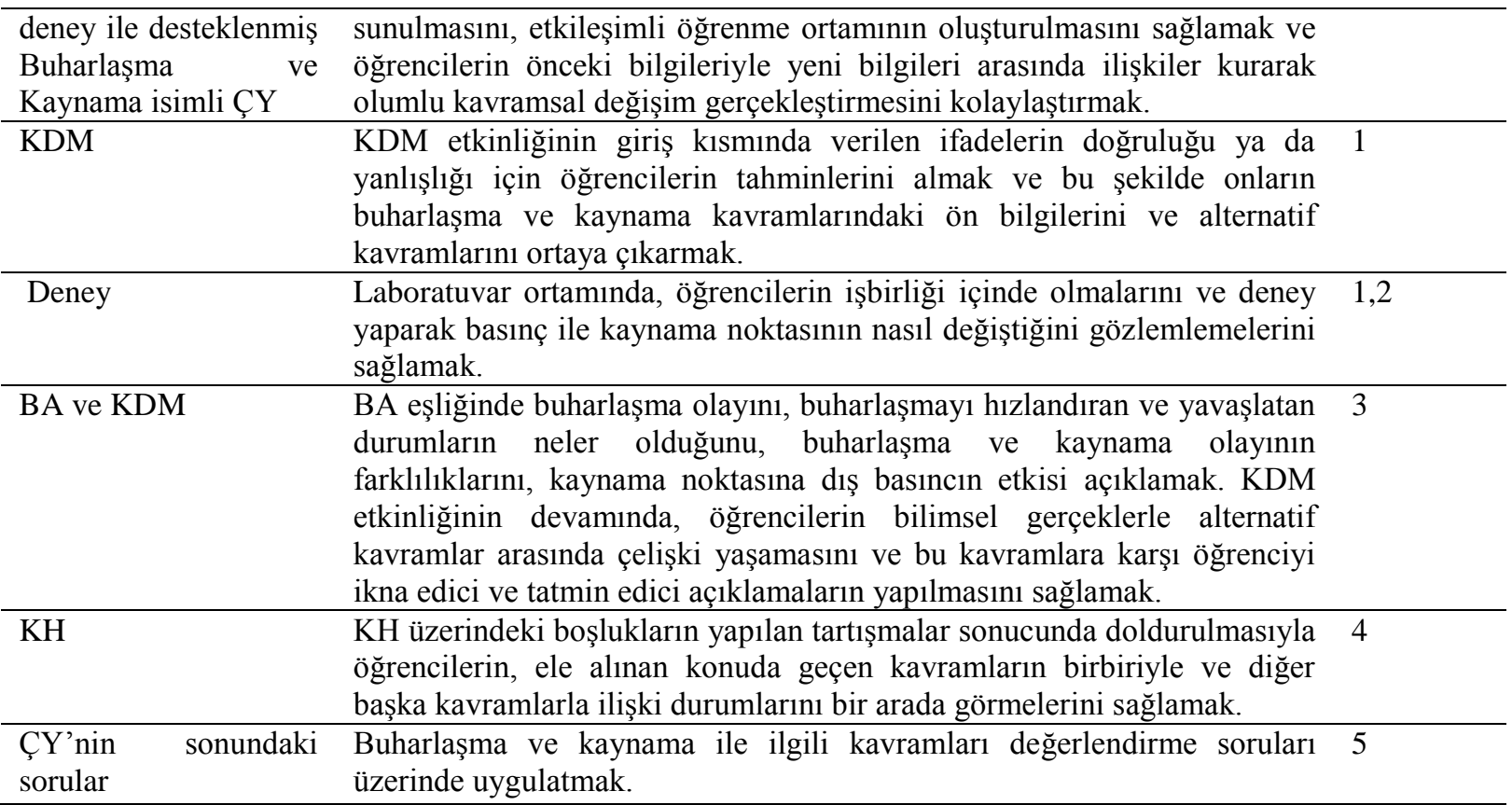

1: Girme, 2: Keşfetme, 3: Açıklama, 4: Derinleştirme, 5: Değerlendirme

Araştırma kapsamında kullanılan ÇY, KDM, KH ve deneyler araştırmacılar tarafindan geliştirilmiştir. BA ise Kimya Eğitimi Araştırma Grubu tarafından geliştirilmiş ve erişime açık internet sitelerinden alınmıştır. Öğretim materyali, çalışmaya ve öğrenci seviyesine uygunluğu ve bilimsel doğruluğu açılarından dört kimya eğitimcisi ve bir fen eğitimcisinin görüşlerine sunulmuştur. Uzman görüşleri doğrultusunda materyaller revize edilerek araştırmanın örneklemine benzer deneyime sahip 28 öğretmen adayına pilot uygulaması yapılmıştır. Bu şekilde geliştirilen öğretim materyalinin işlemeyen noktaları belirlenerek asıl uygulama öncesi gerekli önlemlerin alınması sağlanmıştır. Deney gruplarında yapılan öğretim uygulamasının örnek bir taslağı Tablo 3 'te sunulmuştur.

Tablo 3

Deney Gruplarında Yapılan Öğretim Uygulamasının Örnek Bir Taslă̆ı Aşama Öğretmen adaylarının rolü Öğretmenin rol

Örnek görseller 


\begin{tabular}{llr}
\hline Öğretmen adayları 3 ya da 4 'er \\
kişilik grup oluştururlar. Öğretmen \\
adayları kendilerine $r$ sunulan \\
KDM'nin girişinde örnek bir deney \\
senaryosu üzerinden r verilen \\
sorularının cevaplarının doğruluğu \\
ya da yanlışlığına grup \\
arkadaşlarıyla tartışarak karar \\
vermeye çalışırlar. Bu aşamada \\
öğrencilerin konuya hem merak \\
duymalarını hem de ön bilgilerinin \\
harekete geçmesi amaçlanmaktadır.
\end{tabular}

Öğretmen adayları grup eşliğinde "Basit araç-gereçlerle bir sıvının kaynama noktasına dış basıncın etkisinin nasıl olduğunu denemek isteseydiniz nasil bir deney tasarlardını??" sorusuna tasarı önerilerinde bulunurlar. Daha sonra kendilerine sunulan araç gereçlerle dış basıncın kaynama noktasını nasıl etkilediğini kontrollü deney yaparak denerler. $\mathrm{Bu}$ süreçte, onların hipotez kurma, değişkenleri belirleme, deney yapma, gözlem yapma, veri toplama ve kaydetme, grafik oluşturma, verileri yorumlama ve sonuç çıkarma becerilerini de kullanırlar. Deneyin sonunda verilen deney ile ilgili soruları cevaplandırırlar ve ÇY'nin ilgili yerlerine not alırlar.

Öğretmen adayları buharlaşma olayını, buharlaşmayı hızlandıran ve yavaşlatan durumların neler olduğunu, buharlaşma ve kaynama olayının farklılıklarını, kaynama noktasına diş basıncin etkisi moleküler düzeyde BA'dan izlerler ve öğretmenin giriște sorulan soruların doğru cevaplarına tartışarak ve KDM'nin açıklama kısımlarını okuyarak ulaşmaya çalıșırlar.
Öğretmen, öğretim sürecinde kullanılacak ÇY'yi dağıtır. ÇY'nin giriş bölümünde yer alan KDM'nin ilk kısmındaki soruları (buharlaşma, buharlaşmayı ve buhar basıncını etkileyen faktörler, kaynama, kaynama noktası, kaynama noktasına etki eden faktörler konularıyla ilgili) öğretmen adaylarına yöneltir. Örneğin, "Bence ısıtmanın en başlarında buharlaşma olmadı. Çünkü buharlaşma olması için sıvının belli bir süre 1sıtılması gerekir. Biz buhar oluşumunu su bir hayli isındıktan sonra fark edebildik." İfadesinin doğru ya da yanlış olmasını nedenleriyle belirlemelerini ister. Öğretmen bu esnada interaktif bir tartışma ortamının oluşmasına rehberlik eder. Fakat öğretmen adaylarının verdiği cevapların hiç birini doğru ya da yanlış diye sınıflandırmaz.

Öğretmen öğrencilerin verilen bir probleme yönelik deney tasarlamaları, araç gereçleri kullanarak deney yapmaları ve kaynama noktasına dış basıncın etkisinin ne olduğunu keşfetmeleri için rehberlik eder. Öğretmen deney sonucunda verilen "Yukarıda yapmıs olduğunuz deneyde balon jojenin su olmayan kısmı buz etkisi ile soğutulduğunda sıvinın tekrardan kaynamaya başlama sebebi ne olabilir? Açıklayınız", "Eğer bu işlemi devam ettirseydik suyu daha da düşük sıcaklıklarda kaynatabilir miydik? Ve düşük sıcaklıklarda kaynayan su elimizi yakar mıyd??" sorularını yöneltir.

Öğretmen yapılan tartışmalardan ve deneylerden yola çıkarak konuyu kısaca açıklar. Bunun için sunduğu BA'dan ve KDM'nin açıklama metninden faydalanır. $\mathrm{Bu}$ şekilde öğretmen adaylarının kendi bilgilerinin yapılandırılması sürecine rehberlik eder.
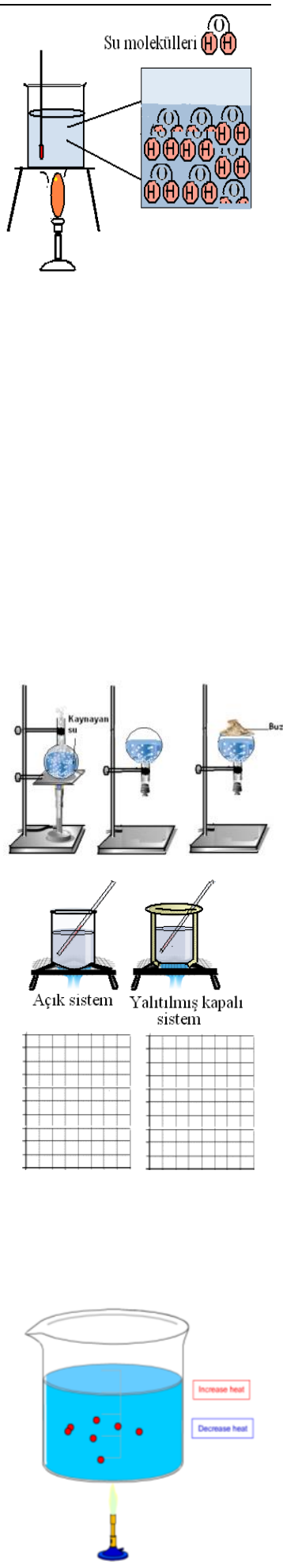


Öğretmen adayları kendilerine $\begin{aligned} & \text { Öğretmen üzerinde boşluklar bulunan } \\ & \text { verilen KH üzerindeki boşlukları }\end{aligned}$ KH’yi öğrencilerin nasıl dolduracağ1
grup arkadaşlarıyla tartışarak
doldururlar. Bu şekilde buharlaşma,

\section{Veri Toplama Aracı ve Analizi}

Veri toplama aracı olarak araştırmacılar tarafından geliştirilen iki aşamalı BKKT kullanılmıştır. İki aşamalı testler, öğrencilerin alternatif kavramları ve anlama seviyeleri hakkında derinlemesine bilgiye ulaşmada sıklıkla kullanılan testlerdir. İki aşamalı BKKT, Treagust ve Chandrasegaran (2007)'ın test geliştirme aşamaları dikkate alınarak ilk kısmı çoktan seçmeli ve ikinci kısmı açık uçlu yapıda hazırlanmıştır. İkinci kısımda açık uçlu bir yapının tercih edilmesinin sebebi, ögrencilerde literatürden tespit edilen alternatif kavramlar haricinde farklı alternatif kavramların olup olmadığını belirlemek ve onların kavramsal değişim seviyeleri hakkında daha detaylı bilgi elde edebilmektir (Voska ve Heikkinen, 2000).

Testleri oluşturan maddelerin, hazırlanma amacına hizmet edebilme özelliği, kapsam geçerliliği, bilimsel doğruluğu, kullanılan dilin açık ve anlaşılırlığı ve cevap anahtarlarının doğruluğu için hazırlanan test, alanında uzman üç kimya eğitimcisi, üç fen eğitimcisi ve iki kimya öğretmeninin incelemesine sunulmuştur. Ayrıca testte anlaşılmayan noktaların belirlenmesi için örneklemden farklı 28 öğretmen adayına pilot uygulama yapılmıştır. 
Birbirinden bağımsız olarak uzmanların incelemeleri arasındaki tutarlılık Cohen’s Kappa katsayısı 0.85 olarak bulunmuştur. Uzmanların incelemelerine göre testte küçük revizyonlar yapılarak teste son hali verilmiştir. Başlangıçta 9 madde şeklinde hazırlanan iki aşamalı BKKT güvenilirlik hesaplamaları için örneklemden farklı 115 öğretmen adayına uygulanmıştır. İki madde, güvenilirliği düşürdüğü için testten çıkarılmıştır. 7 maddeye indirgenen iki aşamalı BKKT için Cronbach Alpha güvenilirlik katsayısı 0,77 olarak hesaplanmıştır. İki aşamalı BKKT’den örnek bir soru aşağıda verilmiştir.

Şekilde verilmiş olan A ve B sıvıları deniz seviyesinde (0 metrede), C sıvısı Ankara'da (900 metrede), $D$ ve $E$ sıvıları ise Ağrı'da (1640 metrede) 1sıtılmaktadır. Buna göre sıvılar,

I. Kaynama noktalarına göre $\mathrm{B}>\mathrm{A}=\mathrm{C}=\mathrm{E}>\mathrm{D}$,

II. Kaynama anındaki buhar basınçlarına göre $\mathrm{A}=\mathrm{B}>\mathrm{C}>\mathrm{D}=\mathrm{E}$,

III. Aynı sıcaklıktaki buhar basınçlarına göre $\mathrm{D}>\mathrm{A}=\mathrm{C}=\mathrm{E}>\mathrm{B}$ şeklinde sıralanırlar. Yukarıda verilen ifadelerden hangileri doğrudur?

a) Yalnız 1 b) Yalnız II c) I ve II d) II ve III e) I, II ve III Lütfen bu şıkkı seçme gerekçenizi aşağıya yazınız:

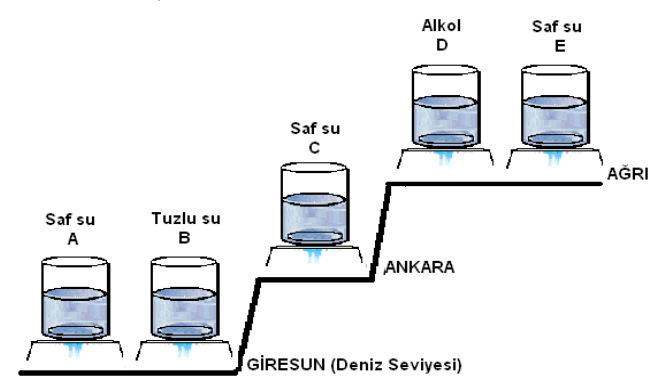

Birçok çalışmada iki aşamalı testlerin analizinde öğrenci cevaplarının kategorilendirilerek puanlandığı görülmektedir (Abraham, Gryzybowski, Renner ve Marek, 1992; Karslı ve Çalık, 2012). Bu araştırmada da iki aşamalı kavram testi analiz edilirken bazı kategoriler kullanılmıştır: Testin birinci aşaması için, doğru seçenek, yanlış seçenek ve boş; ikinci aşaması için ise doğru açıklama, kısmen doğru açıklama ve alternatif kavramlı açıklama / yanlış açıklama ve boş. İki aşamalı BKKT’nin analizinde kullanılan kategoriler, kategorilerin açıklamaları ve bu kategorilere ait puanlamalar Tablo 4'te verilmiştir. 
Tablo 4

BKKT’nin Birinci ve İkinci Aşamalarının Analizinde Kullanılan Kategoriler, Kategorilerin Açılamalart ve Bu Kategorilerin Puanları

\begin{tabular}{|c|c|c|c|c|c|}
\hline \multicolumn{3}{|c|}{ Testin Birinci Aşaması } & \multicolumn{3}{|c|}{ Testin İkinci Aşaması } \\
\hline Kategoriler & Açıklamalar & $\mathbf{P}$ & Kategoriler & Açıklamalar & $\mathbf{P}$ \\
\hline $\begin{array}{l}\text { Doğru } \\
\text { Seçenek } \\
\text { (DS) }\end{array}$ & $\begin{array}{l}\text { Çoktan seçmeli sorular } \\
\text { içerisinden doğru olan } \\
\text { seçeneğin işaretlenmesi }\end{array}$ & 4 & $\begin{array}{l}\text { Doğru Açıklama } \\
\text { (DA) }\end{array}$ & $\begin{array}{lcr}\text { Doğru } & \text { olarak işaretlediği } & \text { seçeneği } \\
\text { seçme } & \text { gerekçesini bilimsel } & \text { açıdan } \\
\text { doğru } & \text { açıklamalar } & \text { yaparak } \\
\text { açıklayabildiyse. } & \end{array}$ & 8 \\
\hline $\begin{array}{l}\text { Yanlış } \\
\text { Seçenek } \\
\text { (YS) }\end{array}$ & $\begin{array}{l}\text { Çoktan seçmeli sorular } \\
\text { içerisinden yanlış olan } \\
\text { seçeneğin işaretlenmesi }\end{array}$ & 1 & $\begin{array}{l}\text { Kısmen } \quad \text { Doğru } \\
\text { Açıllama (KDA) }\end{array}$ & $\begin{array}{l}\text { Yapılan açıklamalar bir kaç yönüyle } \\
\text { sorunun cevabıyla ilişkili fakat yeterli } \\
\text { değil. }\end{array}$ & 6 \\
\hline Boş & $\begin{array}{l}\text { Çoktan seçmeli sorular } \\
\text { içerisinden } \\
\text { seçeneğin }\end{array}$ & 0 & $\begin{array}{l}\text { Alternatif } \\
\text { Kavramlı } \\
\text { Açıklama/ Yanlış } \\
\text { Açılama (AKA) }\end{array}$ & $\begin{array}{l}\text { Bilimsel bilgiyle çelişen ifadeler } \\
\text { içeriyorsa. }\end{array}$ & 2 \\
\hline & & & İlişkisiz-Boş-(B) & $\begin{array}{l}\text { Soruda işaretlediği seçeneğin tekrarını } \\
\text { yazmışsa, ilişkisiz açıklamalar } \\
\text { yapmışsa ve boş bırakmışsa. }\end{array}$ & 0 \\
\hline
\end{tabular}

P: Puan

İki aşamalı BKKT’nin analizinde testin normallik varsayımını karşılayıp karşılamadığına bakılmıştır. Verilerin normalliğini test etmek için çalışma grubunun 50 kişiden fazla olması nedeniyle, One-sample Kolmogorov Smirnov testi uygulanmış (Garcia, Molina, Lozano ve Herrera, 2009) ve verilerin normal dağılım göstermediği anlaşılmıştır. Bu nedenle nicel verilerin analizinde non-parametrik istatistik tekniklerinden faydalanılmıştır. İki aşamalı BKKT'nin deney ve kontrol gruplarının gruplar arası ve grup içi karşılaştırmalarında Mann Whitney U ve Wilcoxon İşaretli Sıralar Testleri kullanılarak istatistiksel analizler yapılmıştır. İki aşamalı BKKT'te öğrencilerin ön ve son testlerdeki 'Buharlaşma ve Kaynama' kavramları ile ilgili sorulara verdikleri cevapların yüzdeleri hesaplanmıştır. Ayrıca 'Buharlaşma ve Kaynama' kavramlarında öğrencilerdeki alternatif kavramların ön test ve son testlerdeki değiş̧imi tablolar eşliğinde verilmiştir. 


\section{Bulgular}

Deney ve kontrol gruplarındaki öğrencilerin BKKT ön ve son test puanlarının Mann-

Whitney U Testi sonuçları Tablo 5'te belirtilmektedir.

Tablo 5.

Deney ve Kontrol Gruplarının Öğrencilerin BKKT Ön Test-Son Test Puanlarına İlişkin Mann-Whitney U-Testi Sonuçlart

\begin{tabular}{|c|c|c|c|c|c|c|c|c|}
\hline Test & Gruplar & $\mathbf{N}$ & Sira Ortalaması & Sira Toplamı & $\mathbf{U}$ & $\mathbf{Z}$ & $p$ & $\eta^{2}$ \\
\hline \multirow{4}{*}{$\begin{array}{c}\text { Ön } \\
\text { test }\end{array}$} & $\mathrm{K} 1$ & 25 & 19.650 & 594.00 & 269.000 & -0.62 & .530 & 0.08 \\
\hline & D1 & 24 & 20.290 & 631.00 & & & & \\
\hline & $\mathrm{K} 2$ & 24 & 19.660 & 579.50 & 279.000 & -0.17 & .860 & 0.03 \\
\hline & D2 & 24 & 18.850 & 596.50 & & & & \\
\hline \multirow{4}{*}{$\begin{array}{l}\text { Son } \\
\text { test }\end{array}$} & K1 & 25 & 23.760 & 594.00 & 166.500 & -4.27 & .000 & 0.61 \\
\hline & D1 & 24 & 33.900 & 813.50 & & & & \\
\hline & $\mathrm{K} 2$ & 24 & 24.150 & 342.50 & 42.500 & -5.38 & .000 & 0.79 \\
\hline & D2 & 24 & 35.350 & 848.50 & & & & \\
\hline
\end{tabular}

K1: Kontrol Grubu 1; D1: Deney Grubu 1; K2: Kontrol Grubu 2; D2: Deney Grubu 2

Tablo 5'te grupların ön test puan karşılaştırmalarından hem K1 ve D1 grupları $\left(\mathrm{U}=269.000, p>.05, \eta^{2}=0.08\right)$ hem de $\mathrm{K} 2$ ve $\mathrm{D} 2$ gruplar1 $\left(\mathrm{U}=279.000, p>.05, \eta^{2}=0.03\right)$ arasında anlamlı bir farklılığın olmadığı görülmektedir. Buna karşın grupların son test puan karş1laştırmalarında ise hem $\mathrm{K} 1$ ve $\mathrm{D} 1$ grupları $\left(\mathrm{U}=166.500, p>.05, \eta^{2}=0.61\right)$ hem de $\mathrm{K} 2$ ve D2 grupları $\left(\mathrm{U}=42.500, p>.05, \eta^{2}=0.79\right)$ arasında deney grupları lehine anlamlı bir farklılığın ve yüksek bir etki değerinin olduğu görülmektedir. Grupların sıra ortalamaları incelendiğinde de deney gruplarındaki öğrencilerin BKKT son test puanlarının kontrol gruplarınınkinden daha yükssek olduğu anlaşılmaktadır.

Tablo 6.

Deney ve Kontrol Gruplarındaki Öğrencilerin BKKT Ön Test-Son Test Puanlarına İlişkin Wilcoxon İsaretli Siralar Testi Sonuçları

\begin{tabular}{|c|c|c|c|c|c|c|c|}
\hline Gruplar & $\begin{array}{c}\text { Son test-Ön } \\
\text { test }\end{array}$ & $\mathbf{N}$ & Sira Ortalaması & $\begin{array}{c}\text { Siralar } \\
\text { Toplamı }\end{array}$ & $\mathbf{Z}$ & $p$ & $\eta^{2}$ \\
\hline \multirow[t]{3}{*}{ K1 } & Negatif Sira & 6 & 10.08 & 60.50 & $-2.559 *$ & 0.01 & 0.51 \\
\hline & Pozitif Sira & 18 & 13.31 & 239.50 & & & \\
\hline & Eşit & 1 & & & & & \\
\hline \multirow[t]{3}{*}{ D1 } & Negatif Sira & 0 & 0.00 & 0.00 & $-4.259 *$ & 0.00 & 0.87 \\
\hline & Pozitif Sira & 23 & 12.00 & 276.00 & & & \\
\hline & Eşit & 1 & & & & & \\
\hline
\end{tabular}




\begin{tabular}{|c|c|c|c|c|c|c|c|}
\hline \multirow[t]{3}{*}{$\mathrm{K} 2$} & Negatif Sira & 4 & 9.12 & 36.50 & \multirow[t]{3}{*}{$-2.923 *$} & \multirow[t]{3}{*}{0.00} & \multirow[t]{3}{*}{0.59} \\
\hline & Pozitif Sira & 18 & 12.03 & 216.50 & & & \\
\hline & Eşit & 2 & & & & & \\
\hline \multirow[t]{3}{*}{ D2 } & Negatif Sira & 0 & 0.00 & 0.00 & \multirow[t]{3}{*}{$-4.287 *$} & \multirow[t]{3}{*}{.000} & \multirow[t]{3}{*}{0.88} \\
\hline & Pozitif Sira & 24 & 12.50 & 300.00 & & & \\
\hline & Eşit & 0 & & & & & \\
\hline
\end{tabular}

Tablo 6'da grupların ön test-son test puanları karşılaştırmalarından K1 grubundaki $(\mathrm{z}=2.559, p<.05) ; \mathrm{K} 2$ grubundaki $(\mathrm{z}=2.923, p<.05) ; \mathrm{D} 1$ grubundaki $(4.259, p<.05)$ ve D2 grubundaki $(\mathrm{z}=4.287, p<.05)$ öğrencilerin BKKT son test puanlarının ön teste göre anlamlı derecede daha yüksek olduğu görülmektedir. Hem deney hem de kontrol gruplarının ön ve son test ikili karşılaştırmalarında etki değerlerine bakıldığında son test lehine anlamlı bir fark olduğu ve bu farkın etkisinin deney gruplarında daha büyük olduğu görülmektedir $(\eta 2=0.87$; $0.88)$.

BKKT'de öğrencilerin ön ve son testlere verdikleri cevaplardan, ön ve son testlerdeki alternatif kavramların yüzdeleri hesaplanmıştır. Bu şekilde deney gruplarında, 'Buharlaşma ve Kaynama' konusunda geliştirilen zenginleştirilmiş laboratuvar rehber materyalinin hangi alternatif kavramlı açıklamaları düzelttiği, hangi alternatif kavramları düzeltmede işe yaramadığı ve bu materyallerin derslerde uygulanması ile öğrencilerin kavramsal anlamalarının nasıl değiştiğinin belirlenmesi amaçlanmıştır. Alternatif kavramların hangi yönde değişim gerçekleştiğini anlayabilmek için ön ve son testler karşılaştırılmış, son testte alternatif kavrama sahip öğrenci sayısı ön testteki alternatif kavrama sahip öğrenci sayısından fazla ise negatif yönde, az ise pozitif yönde kavramsal değișim olduğuna karar verilmiştir. 'Buharlaşma ve Kaynama' kavramlarında öğrencilerin ön ve son testlerdeki alternatif kavramlarının nasıl değiştiği Tablo 7'de verilmiştir.

Tablo 7 
'Buharlaşma ve Kaynama' Konusundaki Alternatif Kavramların Öğrenciler Tarafindan Sahip Olunma Yüzdelerinin Ön ve Son Testlerdeki Değişimi

\begin{tabular}{|c|c|c|c|c|c|c|c|c|c|c|c|c|}
\hline \multirow{2}{*}{$\begin{array}{c}\text { Öğrencilerde Tespit Edilen } \\
\text { Alternatif Kavramlar }\end{array}$} & \multicolumn{3}{|c|}{ K1 Grubu (\%) } & \multicolumn{3}{|c|}{ D1 Grubu (\%) } & \multicolumn{3}{|c|}{ K2 Grubu (\%) } & \multicolumn{3}{|c|}{ D2 Grubu (\%) } \\
\hline & ÖT & ST & KD & ÖT & ST & KD & ÖT & ST & KD & ÖT & ST & KD \\
\hline $\begin{array}{l}\text { Sicaklık artışı olmazsa buharlaşma } \\
\text { olmaz. }\end{array}$ & 4 & - & +4 & - & - & - & 13 & - & +13 & 4 & - & +4 \\
\hline $\begin{array}{llr}\text { Bir buharlaşma } & \text { işleminin } \\
\text { gerçekleşmesi için } & \text { sıvının } \\
\text { kaynaması gerekir. } & \\
\end{array}$ & 8 & 4 & +4 & 8 & - & +8 & 17 & 17 & 0 & 13 & - & +13 \\
\hline $\begin{array}{l}\text { Suyun buharlaşması fiziksel, etil } \\
\text { alkolün buharlaşması } \\
\text { kimyasaldır. }\end{array}$ & - & - & - & 4 & - & +4 & - & - & - & 4 & - & +4 \\
\hline $\begin{array}{l}\text { Buharlaşma her } \text { sicaklıkta olduğu } \\
\text { için sıvının her yerinde, kaynama } \\
\text { ise sadece } \\
\text { gerçekleşir. }\end{array}$ & 12 & 8 & +4 & 8 & - & +8 & 21 & 4 & +17 & 21 & - & +21 \\
\hline $\begin{array}{l}\mathrm{Su} \text { buharlaşırken } \mathrm{H}_{2} \mathrm{O} \text {, kaynarken } \\
\mathrm{H}_{2} \text { ve } \mathrm{O}_{2} \text { şeklinde ayrışarak sıvıyı } \\
\text { gaz halinde terk eder. }\end{array}$ & 4 & - & +4 & 8 & - & +8 & 13 & 4 & +9 & 8 & - & +8 \\
\hline $\begin{array}{lccr}\text { Dışarıdan } & \text { 1sıalan } & \text { bir } & \text { Sıv1 } \\
\text { buharlaşırken } & \text { molekül } & \text { içi } & \text { bağlar } \\
\text { kopar. } & & & \\
\end{array}$ & 20 & 12 & +8 & 21 & - & +21 & 50 & 42 & +8 & 42 & - & +42 \\
\hline $\begin{array}{l}\text { Etil alkol } \quad \text { buharlaşırken } \\
\text { kabarcıklarda } \mathrm{O}_{2} \text { gazı, tuzlu su } \\
\text { buharlaşırken } \mathrm{H}_{2} \mathrm{O} \text { bileşenlerine } \\
\text { ayrıldığından kabarcıklarda } \mathrm{H}_{2} \text { ve } \\
\mathrm{O}_{2} \text { gazları bulunur. }\end{array}$ & 4 & 4 & 0 & 13 & - & +13 & 8 & 8 & 0 & 8 & - & +8 \\
\hline $\begin{array}{l}\text { Etil alkol ve tuzlu su 1sıtıldıkça } \\
\text { kabarcıklarının içinden } \mathrm{CO}_{2} \text { gazları } \\
\text { çıar. }\end{array}$ & 8 & - & +8 & - & - & - & - & - & - & - & - & - \\
\hline $\begin{array}{l}\text { Kaynatılan yer kaynama noktasını } \\
\text { değil kaynama süresini etkiler. } \\
\text { Kaynama noktası kaynatılan yerden } \\
\text { etkilenmez. }\end{array}$ & 44 & - & +44 & 13 & - & +13 & 33 & 21 & +12 & 46 & 13 & +33 \\
\hline $\begin{array}{lcc}\text { Is1 kaynağının güçlü } & \text { olması } \\
\text { kaynama noktasını arttırır. } & \\
\end{array}$ & 4 & - & +4 & 8 & 4 & +4 & 4 & 4 & 0 & 13 & 4 & +9 \\
\hline $\begin{array}{l}\text { Sivının saflığı kaynama noktasını } \\
\text { etkilemez. }\end{array}$ & 4 & 4 & 0 & 4 & - & +4 & - & - & - & 8 & - & +8 \\
\hline $\begin{array}{l}\text { Saf bir sıvıya katı bir madde } \\
\text { eklendiğinde kaynama noktası } \\
\text { azalır. }\end{array}$ & 12 & 28 & -16 & 17 & 4 & +13 & 4 & 13 & -9 & 21 & 4 & +17 \\
\hline $\begin{array}{l}\text { Buhar basınc1 ile kaynama noktası } \\
\text { doğru orantılıdır. }\end{array}$ & 16 & 20 & -4 & 2 & - & +2 & 4 & 13 & -9 & 4 & - & +4 \\
\hline $\begin{array}{l}\text { Kabın açık ya da kapalı olması } \\
\text { kaynama noktasını etkilemez. }\end{array}$ & 4 & - & +4 & 4 & 4 & 0 & 13 & - & +13 & 8 & 4 & +4 \\
\hline $\begin{array}{l}\text { Kapalı kapta kaynama noktası daha } \\
\text { düşüktür. }\end{array}$ & - & - & - & 8 & - & +8 & - & 4 & -4 & 4 & - & +4 \\
\hline $\begin{array}{l}\text { Dış basınç azalırsa kaynama noktası } \\
\text { artar. }\end{array}$ & 8 & 8 & 0 & 4 & 4 & 0 & 4 & - & +4 & - & - & - \\
\hline $\begin{array}{l}\text { Yükseğe çıkıldıkça dış basınç artar, } \\
\text { sıvının kaynama noktası artar. }\end{array}$ & 8 & 8 & 0 & 8 & - & +8 & 13 & 8 & +5 & - & - & - \\
\hline
\end{tabular}




\begin{tabular}{|c|c|c|c|c|c|c|c|c|c|c|c|c|}
\hline $\begin{array}{l}\text { Aynı bölgede bütün sıvıların } \\
\text { kaynama noktası aynıdır. }\end{array}$ & & 4 & 0 & 4 & - & +4 & & & & 4 & - & +4 \\
\hline $\begin{array}{l}\text { Kaynama esnasında } 1 \text { sı verilmeye } \\
\text { devam edilirse maddenin kinetik } \\
\text { enerjisi ve sıcaklığı artar. }\end{array}$ & 36 & 16 & +20 & 38 & 25 & +13 & 21 & 17 & +4 & 33 & 21 & +12 \\
\hline $\begin{array}{l}\text { Kaynama anında sıvının buhar } \\
\text { basıncı açık hava basıncından } \\
\text { farklıdır. }\end{array}$ & - & 4 & -4 & 4 & - & +4 & 4 & - & +4 & 4 & - & +4 \\
\hline $\begin{array}{l}\text { Aynı sıcaklıkta suyun buhar basıncı } \\
\text { deniz seviyesinde yükseklere göre } \\
\text { daha fazladır. }\end{array}$ & 4 & 4 & 0 & 4 & 4 & 0 & - & 4 & -4 & 13 & 8 & +5 \\
\hline $\begin{array}{l}\text { Aynı ortamda kaynayan, } \\
\text { birbirinden farklı sıvıların buhar } \\
\text { basıçları farklıdır. }\end{array}$ & & 4 & +12 & 1 & - & +1 & 13 & 8 & +5 & 17 & 4 & +13 \\
\hline $\begin{array}{l}\text { Sivının ilk sicaklığı o sıvının } \\
\text { kaynama noktasını etkiler. } *\end{array}$ & 4 & 4 & 0 & 4 & - & +4 & 4 & 4 & 0 & 4 & - & +4 \\
\hline \multicolumn{13}{|c|}{$\begin{array}{l}\text { ÖT: Ön Test; ST: Son Test; KD: Kavramsal Değişim; (+) işareti öğretim sonrasında ön testten son teste } \\
\text { öğrencilerde gerçekleşen olumlu kavramsal değişimi; (-) işareti öğretim sonrasında ön testten son teste } \\
\text { öğrencilerde gerçekleşen olumsuz kavramsal değişimi ifade etmektedir. }\end{array}$} \\
\hline
\end{tabular}

Tablo 7'den deney ve kontrol gruplarındaki öğrencilerin ön testlerinden 'Buharlaşma ve Kaynama' konusunda çok sayıda alternatif kavramlı açıklamalar yaptığı görülmektedir. Bu öğrencilerin son testlerde yaptıkları açıklamalar incelendiğinde ise bütün grupların alternatif kavram sayısında azalma olduğu bununla birlikte deney gruplarında alternatif kavramlı açıklama yapan öğrencilerin sayısının daha fazla oranda azaldığı görülmektedir. Örneğin, ön testte buharlaşma kavramı ile ilgili “Sıcaklık artışı olmazsa buharlaşma olmaz." şeklinde belirlenen alternatif kavrama ön testte kontrol gruplarında toplamda \% 17 oranında rastlanırken, son testte hiçbir öğrencide bu alternatif kavrama rastlanmamıştır. Benzer şekilde deney gruplarında ön testte $\% 4$ oranında bu alternatif kavrama rastlanırken, son testte hiçbir öğrencide rastlanmamıştır. Bu alternatif kavramda uygulamalar sonrasında olumlu yönde kavramsal değişim sağlandığı anlaşılmaktadır. Bir başka örnekte ise "Buhar basıncı ile kaynama noktası doğru orantılıdır. Buhar basıncı arttıkça, tanecikler arası çekim kuvveti ve kaynama noktası artar.” şeklindeki alternatif kavrama kontrol gruplarında ön testte toplam \% 
20, son testte ise \% 33 oranında rastlanmıştır. Bu alternatif kavramda uygulamalar sonrasında negatif yönde kavramsal değişimin olduğu (-) anlaşılmaktadır. Ancak deney gruplarında bu alternatif kavramda pozitif yönde bir kavramsal değişimin olduğu anlaşılmaktadır.

\section{Tartışma ve Sonuç}

Tablo 5’ten deney ve kontrol gruplarındaki öğrencilerin BKKT ön test puanlarının çok yakın olduğu anlaşılmaktadır. Bu durum öğretim uygulamasının öncesinde deney ve kontrol gruplarındaki öğrencilerin 'Buharlaşma ve Kaynama' konusundaki kavramsal anlamalarının kendi içlerinde birbirine eş değer olduğunu göstermektedir. Öğrencilerin benzer ön bilgilere sahip olmasında, öğrencilerin Lisans Yerleştirme Sınav'ından benzer puanlar alarak sınıflara yerleştirilmesi ve okutulan fen derslerinin bütün sınıflarda ortak olması etkili olmuş olabilir. Öğrencilerin ön test puanlarının birbirine yakın çıkması, uygulanan rehber materyallerin etkililiklerinin son testlere göre karşılaştırılabilmesinde önemli bir avantaj olarak görülebilir. Buna karşın her iki deney grubunda da kontrol gruplarına göre son test puanlarının anlamlı derecede daha yüksek olmasından zenginleştirilmiş laboratuvar rehber materyalinin öğretmen adaylarının 'Buharlaşma ve Kaynama' konusunda kavramsal anlamalarını daha fazla arttırdığı, dolayısıyla pozitif yönde bir kavramsal değişim sağlamasında daha etkili olduğu anlaşılmaktadır. $\mathrm{Bu}$ durumun nedeni, deney gruplarında $\mathrm{KDM}, \mathrm{BA}, \mathrm{KH}$ ve deney etkinliklerinin ÇY eşliğinde entegre edilerek sunulması olabilir. Başka bir ifadeyle araştırmada kavramsal değişim amaçlı kullanılan kavram öğretim araçlarının, birbirinin zayıf ve eksik kısımlarını gidererek daha zengin bir öğrenme ortamı oluşmasında etkili olmuş olabilir (Karslı, 2011; Karslı ve Ayas, 2013b; Karslı ve Çalık, 2012; Özmen, Demircioğlu ve Demircioğlu, 2009). Bodner (1990)'ın da belirttiği gibi öğrenme sürecinde daha aktif olan ve kendi görev aldığı öğrenme sürecinde bilgiyi kazanan öğrenciler daha iyi 
öğrenebilmektedirler. Nitekim araştırma kapsamında kullanılan öğretim araçları öğrencileri daha aktif hale getirmiş ve aldıkları görevleri sorumluluk içinde yapmış olabilirler. Buna ek olarak deney gruplarındaki öğrencilerin BKKT puanlarının daha yüksek olmasında, uygulamalar kapsamında kullanılan zenginleştirilmiş laboratuvar rehber materyalinin öğrencilerde tespit edilen alternatif kavramların neler olduğu belirlenerek tasarlanması da etkili olmuş olabilir (Karslı ve Kara Patan, 2016; Karslı ve Yiğit, 2015, 2016). Çünkü kavram öğretim yöntem ve tekniğinin, öğrencilerde muhtemel alternatif kavramlar göz önünde bulundurularak kullanılması kavram öğretiminin etkinliğini arttırmaktadır (Çayan ve Karslı, 2015). Aynı zamanda kontrol gruplarında uygulanan anlatım, soru-cevap ve deney yöntemlerinin de öğretmen adaylarının deney gruplarındaki kadar fazla olmasa da pozitif yönde kavramsal değişim gerçekleştirmesinde etkili olduğu anlaşılmaktadır. Aslında bütün eğitimciler yapılan öğretim sonrasında öğrencilerin temel içerik hakkında bir şeyler öğrenmesini beklerler (Sadler, 2009). Ancak deney gruplarında yapılan öğretim, kontrol gruplarında yapılan öğretime göre daha derinlemesine bir kavramsal değişim sağlamıştır. Çünkü deney gruplarındaki öğrenciler son testte kontrol gruplarına göre daha fazla oranda alternatif kavramlarını doğrularıyla değiştirebilmişlerdir (Bkz. Tablo 7). Çoğu araştırma sonucunda geleneksel öğretimin, derin bir şekilde kök salmış alternatif kavramların giderilmesinde çok daha az bir etkiye sahip olduğu belirlenmiştir (Karslı ve Ayas, 2014).

$\mathrm{Bu}$ araştırma sonucunda 'Buharlaşma ve Kaynama' kavramları ile ilgili öğretmen adaylarında BKKT'nin analizinden literatürde daha önceden de belirlenen birçok alternatif kavram tespit edilmiştir. Örneğin bu araştırmada belirlenen "Sıcaklık artışı olmazsa buharlaşma olmaz." ve "Bir buharlaşma işleminin gerçekleşmesi için sıvının kaynaması gerekir." alternatif kavramlara benzer bir alternatif kavram Coştu ve Ayas (2005)'ın 
çalışmasında da rapor edilmiştir. Öğretimden önce ön testte böyle bir alternatif kavrama rastlanılmasının sebebi, buharlaşma olayının sadece sıvının yüzeyinde buhar varsa gerçekleştiğini ve günlük hayatlarından buharın sıcaklık arttırıldığında hızlandığını görmeleri olabilir (Karsl1, 2011; Karslı ve Ayas, 2013). Tablo 7'den bu alternatif kavrama sahip olan öğrencilerin çoğunun öğretim sonrasında olumlu kavramsal değişim gerçekleştirdiği görülmektedir. Bu durum deney ve kontrol gruplarında öğretim sürecinde; "Buharlaşma her sıcaklıkta olur, soğuk havalarda da çamaşırların kuruması buna örnektir.” şeklinde açıklamalar yapılmasının bir sonucu olabilir. Buna ek olarak bu konuda yapılan deneyde ağzı kapatılmış balon jojede bulunan kaynamış su soğutulduğunda alçak basıncın etkisiyle kaynamış ve buharlaşma daha da artmıştır. Bu deney yapıldıktan sonra öğrencilerin zihinlerinde soğuk ortamlarda da buharlaşmanın gerçekleşebildiği düşüncesi yerleşmiş olabilir. Çeşitli çalışma sonuçlarında farklı öğrenci gruplarında da bu araştırmadakine benzer alternatif kavramlar ortaya çıkmıştır (Coştu ve diğ., 2007; Hwang ve Hwang, 1990; Karslı ve Ayas, 2013; Varelas ve diğ., 2006). Ayrıca 'Buharlaşma ve Kaynama' kavramları ile ilgili öğretmen adaylarında tespit edilen alternatif kavramların olası nedenleri Karslı ve Ayas'ın (2013a) araştırmalarında da detaylıca tartışılmıştır.

Tablo 7 incelendiğinde 'Buharlaşma ve Kaynama' konusunda deney gruplarında öğretim öncesinde alternatif kavramlara sahip olan öğrencilerin büyük bir çoğunluğu ya da tamamı öğretim sonrasında bu alternatif kavramlarını gidermiştir. Deney gruplarındaki öğrencilerin alternatif kavramlarında gözlemlenen bu azalma, öğretimin ardından çoğu öğretmen adaylarının fikirlerinde olumlu yönde bir kavramsal değişimin gerçekleştiğine işarettir. Olumlu yönde kavramsal değişim gerçekleştirmede deney gruplarının daha başarılı olmasında, deney gruplarında KDM etkinliğinde alternatif kavramlı durumların sınıfta 
tartışılması ve bilimsel doğrularının açıklanması etkili olmuş olabilir. $\mathrm{Bu}$ tartışmalar öğrencilerin fikirlerini paylaşma ve derinlemesine düşünmelerinde yardımcı olmuş, öğretmenöğrenci etkileşiminin de artarak etkili bir öğretimin meydana gelmesine neden olmuş olabilir. $\mathrm{Bu}$ durum KDM’nin üniversite öğrencilerinin kavramsal değişimlerine yardımcı olduğu (Diakidoy, Kendeou ve Ioannides, 2003) sonucuyla açıklanabilir. KDM etkinliğinin yanı sıra KH etkinliği de olumlu yönde kavramsal değişimde rol almış olabilir. Çünkü KH'de sıvıların kaynama noktasını etkileyen ve etkilemeyen faktörlerin neler olduğuna yönelik boşluklar öğrencilerle tartışılarak ve örnekler verilerek birlikte doldurulmuştur. Bunun yanında kavramlarla ilgili birçok özelliği kendi yaptıkları etkinlikler aracılığıyla inceleme fırsatı bulan öğrenciler, kavramları alternatif kavramlardan uzak bir biçimde bilimsel olarak doğru ilişkiler kurarak yapılandırmış olabilirler (Coştu ve diğ., 2003). 'Buharlaşma ve Kaynama' konusunda ÇY'nin (Gönen ve Akgün, 2005; Karslı ve Yiğit, 2016), 5E’nin (Demircioğlu, Demircioğlu ve Vural, 2016) ve animasyonların (Papageorgiou ve diğ., 2008) kullanıldığı çalışmalarda bu yöntemlerin öğrencilerin kavramsal anlamalarını arttırdığı tespit edilmiştir. Araştırmalarda farklı öğrenci sayısına bağlı olarak bir o kadar çeşitli öğretim yöntemlerinin geliştirilmesi ve uygun şekilde sunulması gerektiği vurgulanmaktadır (Karslı ve Ayas, 2014; Karslı ve Çalık, 2012). Bu bağlamda 'Buharlaşma ve Kaynama' konusunda deney gruplarına uygulanan materyaldeki ÇY, deney, KDM, BA ve $\mathrm{KH}$ etkinliklerinin birlikte kullanılmasının, öğrencilerin olumlu yönde kavramsal değişim gerçekleştirmelerini sağladığı yorumu yapılabilir. Nitekim Özmen (2011)'de KDM-BA kombinasyonunun öğrencilerin kimya kavramlarını anlamalarını geliştirdiğini tespit etmiştir. Benzer olarak kontrol gruplarındaki öğretmen adaylarının alternatif kavramları da deney grupları kadar olmasa da öğretim uygulamalarından sonra bilimsel olanlarla değiştirilmiştir. Ancak kontrol gruplarında 
alternatif kavramların bir kısmı tamamen giderilememiş, hatta negatif yönde bir kavramsal değişim de bazen gözlenmiştir. Kontrol gruplarındaki bazı öğrencilerin alternatif kavramlarını tamamen gidermesinde öğrencilerin grupla birlikte deney yaptı̆̆ 1 için grup arkadaşlarıyla fikir alışverişinde bulunmaları etkili olmuş olabileceği gibi öğrencilerin zihinlerinde hem bilimsel kavramların hem de alternatif kavramların bulunması durumunda son testte egemen olan anlayışın bilimsel kavramlardan oluşması da olabilir. Bazı öğrencilerin alternatif kavramlarında bir değişme olmaması ise kontrol gruplarına uygulanan anlatım, soru-cevap ve kapalı uçlu deney yöntemlerinin öğrencilerin alternatif kavramlarını azaltmada yetersiz kalması ile açıklanabilir. Kontrol gruplarındaki öğrencilerden bazılarının öğretimden sonra alternatif kavram sayısında artma olması ise şaşırtıcı bir durumdur. Ancak çeşitli araştırmalarda öğrencilere yapılan müdahaleler sonucunda negatif yönde kavramsal değişim meydana gelebileceğine yönelik çalışma bulgularına da rastlanılmaktadır (Ebenezer, 2001). Fakat öğretim uygulamaları hiçbir öğrencide yeni alternatif kavramlar oluşturmamıştır.

Çalışmada ortaya çıkan sonuçlara dayalı olarak, farklı konularda farklı öğrenci seviyelerine yönelik farklı kavramsal değişim yöntem ve teknikleriyle zenginleştirilmiş öğrenme ortamları hazırlanıp uygulanabilir. Materyaller geliştirilirken uygulayıcıların ihtiyaç duyabileceği tüm detayları içeren kılavuzlar hazırlanmalıdır.

\section{Makalenin Bilimdeki Konumu (Yeri)}

Matematik ve Fen Bilimleri Eğitimi Bölümü / Fen Bilgisi Eğitimi Anabilim Dalı

\section{Makalenin Bilimdeki Özgünlüğü}

Günlük hayatımızda birebir şahit olduğumuz 'Buharlaşma ve Kaynama', soyut olmasından dolayı, ilköğretim, lise ve üniversite seviyesindeki öğrencilerce alternatif kavramlara sıklıkla rastlanan konulardan biri olarak değerlendirilmektedir. Öğretmen 
adaylarının bu kavramlarla mezun olmaları durumunda, onlar öğretmen olduklarında öğretimleri sırasında bu alternatif kavramları kendi öğrencilerine taşıyabilirler. Bu araştırmada birçok öğrencinin 'Buharlaşma ve Kaynama' kavramlarında alternatif kavramlara sahip olması ve kavramsal değişime yönelik çalışmalara ihtiyaç duyulmasından yola çıkılarak bu kavramlara yönelik Bilgisayar Animasyonları (BA), Kavram Haritası (KH), Kavramsal Değişim Metni (KDM) ve deney etkinliklerinin, Çalışma Yaprağı (ÇY) eşliğinde 5E öğretim modelinin aşamalarına entegre edilerek laboratuvar ortamında kullanımı sağlanmıştır. Farklı kavramsal değişim yöntem/tekniklerle zenginleştirilmiş bu materyalin fen bilimleri öğretmen adaylarının kavramsal değişimlerine etkisinin incelenmesinin ve sonuçlarının paylaşılmasının literatüre katkı sağlayacağına inanılmaktadır.

\section{Kaynaklar}

Abraham, M. R., Gryzybowski, E. B., Renner, J. W., \& Marek, A., E. (1992). Understanding and misunderstanding of eighth graders of five chemistry concepts found in textbooks. Journal of Research in Science Teaching, 29(2), 105-120.

Aktamış, H., \& Ergin, Ö. (2007). Bilimsel süreç becerileri ile bilimsel yaratıcılık arasındaki ilişkinin belirlenmesi. Hacettepe Üniversitesi Eğitim Fakültesi Dergisi, 33, 11-23.

Anderson, C. W. (2007). Perspectives on science learning. In S. K. Abell \& N. G. Lederman (Eds.), Handbook of research on science education (pp. 3-30). Mahwah, NJ: Erlbaum.

Ayas, A., \& Demirbaş, A. (1997). Turkish secondary students' conception of introductory chemistry concepts. Journal of Chemical Education, 74(5), 518-521.

Ayas, A., Özmen, H., \& Çalık, M. (2010). Students' conceptions of the particulate nature of matter at secondary and tertiary level. International Journal of Science and Mathematics Education, 8(1), 165-184. DOI: 10.1007/s10763-009-9167-x 
Bar, V., \& Galili, I. (1994). Stages of children's views about evaporation. International Journal of Science Education, 16(2), 157-174.

Bar, V., \& Travis, A. S. (1991). Children's views concerning phase changes. Journal of Research in Science Teaching, 28(4), 363-382.

Beveridge, M. (1985). The development of young children's understanding of the process of evaporation. British Journal of Educational Psychology, 55(1), 84-90.

Bodner, G. M. (1990). Why good teaching fails and hard-working students do not always succeed. Spectrum, 28(1), 27-32.

Canpolat, N. Pinarbasi, T., \& Sözbilir, M. (2006). Prospective teachers' misconceptions of vaporization and vapor pressure. Journal of Chemical Education, 83(8), 1237. DOİ: 10.1021/ed083p1237.

Canpolat, N., Pınarbaşı, T., Bayrakçeken, S., \& Geban, Ö. (2004). Kimyadaki bazı yaygın yanlış kavramalar. Gazi Üniversitesi Ĕ̌itim Fakültesi Dergisi, 24(1), 135-146.

Carey S., Evans, R., Honda, M., Jay, E., \& Unger, C. (1989). An experiment is when you try it and see if it works": A study of grade 7 students' understanding of the construction of scientific knowledge. International Journal of Science Education, 11(5), 514-529.

Chang, J. Y. (1999). Teacher college students' conceptions about evaporation, condensation, and boiling. Science Education, 83(5), 511-526.

Coştu, B., \& Ayas, A. (2005). Evaporation in different liquids: secondary students' conceptions. Research in Science \& Technological Education, 23(1), 75-97, DOI: $10.1080 / 02635140500068476$.

Coştu, B., \& Ünal, S. (2005). Le-Chatelier prensibinin çalışma yaprakları ile öğretimi. Yüzüncü Yıl Üniversitesi Elektronik Ĕ̈itim Fakültesi Dergisi, 1(1), 1-10. 
Coştu, B., Ayas, A., Niaz, M., Ünal, S., \& Çalık, M. (2007). Facilitating conceptual change in students' understanding of boiling concept. Journal of Science Education Technology, 16(6), 524-536. DOI:10.1007/s10956-007-9079-x

Coştu, B., Karataş, F. Ö., \& Ayas, A. (2003). Kavram öğretiminde çalışma yapraklarının kullanılması. Pamukkale Üniversitesi Eğitim Fakültesi Dergisi, 14(2), 33-48.

Çayan, Y., \& Karslı, F. (2015). 6. sınıf öğrencilerinin fiziksel ve kimyasal değişim konusundaki kavram yanılgılarının giderilmesinde probleme dayalı öğrenme yaklaşımının etkisi. Kastamonu Ĕ̆itim Dergisi, 23(4), 1433-1448.

Demircioğlu, G., Demircioğlu, H., \& Vural, S. (2015). 5e öğretim modelinin üstün yetenekli öğrencilerin buharlaşma ve yoğuşma kavramlarını anlamaları üzerine etkisi. Kastamonu Ĕ̈itim Dergisi, 24(2), 821-838.

Diakidoy, I. N., Kendeou, P., \& Ioannides, C. (2003). Reading about energy: The effects of text structure in science learning and conceptual change. Contemporary Educational Psychology, 28(3), 335-356.

Driver, R., \& Easley, J. (1978). Pupils and paradigms: a review of literature related to concept development in adolescent science students. Studies in Science Education, 5, 61-84.

Duit, R., \& Treagust, D. F. (2003). Conceptual change: A powerful framework for improving science teaching and learning. International Journal of Science Education, 25(6), 671-688, DOI: 10.1080/09500690305016.

Ebenezer, J. (2001). A hypermedia environment to explore and negotiate students' conceptions: animation of the solution process of table salt. Journal of Science Education and Technology, 10(1), 73-91. 
Finley, F. N., Stewart, J., \& Yarroch, W. L. (1982). Teachers' perceptions of important and difficult science content. Science Education, 66(4), 531-538.

Garcia, S., Molina, D., Lozano, M., \& Herrera, F. (2009). A study on the use of non-parametric tests for analyzing the evolutionary algorithms' behaviour: a case study on the CEC'2005 special session on real parameter optimization. Journal of Heuristics, 15(6), 617-644.

Gonzalez, F. M. (1997). Diagnosis of spanish primary school students' common alternative science concepts. School Science and Mathematics, 97(2), 68-74.

Goodwin, A. (2000). The teaching of chemistry: Who is the learner? Chemistry Education Research and Practice in Europe, 1(1), 51-60.

Gönen, S., \& Akgün, A. (2005). Bilgi eksiklikleri ve kavram yanılgılarının tespiti ve giderilmesinde, çalışma yaprakları ve sınıf içi tartışma yönteminin uygulanabilirliği üzerine bir araştırma. Elektronik Sosyal Bilimler Dergisi, 4(13), 99-111.

Hatzinikita V., \& Koulaidis, V. (1997). Pupils' ideas on conservation during changes in the state of water. Research in Science and Technological Education, 15(1), 53-71.

Hwang, B. T., \& Hwang, H. W. (1990). A Study of Cognitive Development of the Concepts of Solution, Research Report, Taipei, Republic of China: National Science Council.

Hyslop-Margison, E. J., \& Strobel, J. (2007). Constructivism and education: Misunderstandings and pedagogical implications. The Teacher Educator,43(1), 72-86, DOI: $10.1080 / 08878730701728945$.

Johnson, P. (1998). Children's understanding of changes of state involving the gas state, Part 1: Boiling water and the particle theory. International Journal of Science Education, 20(5), $567-583$. 
Karslı, F. (2011). Fen bilgisi ögretmen adaylarinin bilimsel süreç becerilerini geliştirmesinde ve kavramsal değişim sağlamasında zenginleştirilmiş laboratuvar rehber materyallerinin etkisi. (Yayımlanmamış doktora tezi), Karadeniz Teknik Üniversitesi, Trabzon.

Karsl, F., \& Ayas, A. (2013a). Prospective science teachers' alternative conceptions about the chemistry issues. Necatibey Faculty of Education Electronic Journal of Science and Mathematics Education, 7(2), 284-313.

Karsl1, F., \& Ayas, A. (2013b). Is it possible to eliminate alternative conceptions and to improve scientific process skills with different conceptual change methods? 'An example of electrochemical cells? Journal of Computer and Educational Research, 1(1), 1-26.

Karsl1, F., \& Ayas, A. (2014). Developing a laboratory activity by using 5e learning model on student learning of factors affecting the reaction rate and improving scientific process skills. Procedia-Social and Behavioral Sciences, 143, 663-668.

Karslı, F., \& Çalık, M. (2012). Can freshman science student teachers' alternative conceptions of ‘electrochemical cells' be fully diminished? Asian Journal of Chemistry, 23(12), 485-491.

Karsl1, F., \& Kara Patan, K. (2016). Effects of the context- based approach on students' conceptual understanding: "The Umbra, the Solar Eclipse and the Lunar eclipse", Journal of Baltic Science Education, 15(2), 246-260.

Karsl1, F., \& Şahin Ç. (2009). Developing worksheet based on science process skills: factors affecting solubility. Asia-Pasific Forum of Learning and Teaching, 10(1), Article 15.

Karsl1, F., \&Yiğit, M. (2015). Effect of context-based learning approach on 12 grade students' conceptual understanding about alkanes. Inonu University Journal of the Faculty of Education, 16(1), 43-62. DOI:10.17679/iuefd.16124860. 
Karsl1, F., \& Yiğit, M. (2016). 12 $2^{\text {th }}$ grade students' views about an Alkanes Worksheet Based on the REACT Strategy. Necatibey Faculty of Education Electronic Journal of Science and Mathematics Education, 10(1), 472-479.

Kayalı, H. A., \& Tarhan, L. (2004). İyonik bağlar konusunda kavram yanilgilarinin giderilmesi amacıyla yapılandırmacı aktif öğrenmeye dayalı bir rehber materyal uygulaması. Hacettepe Üniversitesi Ĕ̈itim Fakültesi Dergisi, 27, 145-154.

Koray, Ö., Köksal, M. S., Özdemir, M., \& Presley, A. İ. (2007). The effect of creative and critical thinking based laboratory applications on academic achievement and science process skills. Elementary Education Online, 6(3), 377-389.

Lee, A. T., Hairston, R. V., Thames, R., Lawrence, T., \& Herron, S. S. (2002). Using a computer simulation to teach science process skills to college biology and elementary education majors. Computer Simulations Bioscene, 28(4), 35- 42.

McElwee, P. (1991). Transition from personal to Scientific understanding. Research in Science and Technological Education, 9(2), 139-156.

Mills, R., Tomas, L., \& Lewthwaite, B. (2016). Learning in Earth and space science: A review of conceptual change instructional approaches. International Journal of Science Education, $38(5), 767-790$

Mutlu, A., \& Acar Şeşen, B. (2016). Evaluating of preservice science teachers' understanding of general chemistry concepts by using two tier diagnostic test. Journal of Baltic Science Education, 15(1), 79-96.

Nakhleh, M. B,. \& Krajcik, J. S. (1994). Influence of levels of information as presented by different technologies on students' understanding of acid, base, and $\mathrm{pH}$ concepts. Journal of Research in Science Teaching, 34(10), 1077-1096. 
Nieswandt, M. (2001). Problems and possibilities for learning in an introductory chemistry course from a conceptual change perspective. Science Education, 85(2), 158-179.

Orgill, M., \& Bodner, G. (2004). What research tells us about using analogies to teach chemistry. Chemistry Education Research and Practice in Europe, 5(1), 15-32.

Osborne, R., \& Cosgrove, M. (1983). Children's conceptions of the changes of state of water. Journal of Research in Science Teaching, 20(9), 825-838.

Özmen, H. (2011). Effect of animation enhanced conceptual change texts on 6th grade students' understanding of the particulate nature of matter and transformation during phase changes. Computers \& Education, 57(1), 1114-1126

Özmen, H., Demircioğlu, H., \& Demircioğlu, G. (2009). The effects of conceptual change texts accompanied with animations on overcoming 11th grade students' alternative conceptions of chemical bonding. Computers \& Education, 52(3), 681-695.

Paik, S. H., Kim, H. N., Cho, B. K., \& Park, J. W. (2004). K-8th grade Korean students' 'conceptions of changes of state' and 'conditions for changes of state'. International Journal of Science Education, 26(2), 207-224.

Papageorgiou, G., Johnson, P., \& Fotiades, F. (2008) Explaining melting and evaporation below boiling point. Can software help with particle ideas? Research in Science \& Technological Education, 26(2), 165-183. DOI: 10.1080/02635140802037336.

Pınarbaşı, T., \& Canpolat, N. (2003). Students understanding of solutions chemistry concepts. Journal of Chemistry Education, 80(11), 1328-1332.

Posner, G. J., Strike, K. A., Hewson, P. W., \& Gertzog, W. A. (1982). Accommodation of a scientific conception: Toward a theory of conceptual change. Science education, 66(2), 211-227. 
Prain, P., Tytler, R., \& Peterson, S. (2009). Multiple representation in learning about evaporation. International Journal of Science Education, 31(6), 787-808. DOI: $10.1080 / 09500690701824249$.

Reid, N. (2008). A scientific approach to the teaching of chemistry. What do we know about how students learn in the sciences, and how can we make our teaching match this to maximise performance? Chemistry Education Research and Practice, 9(1), 51-59. DOI: $10.1039 / B 801297 K$.

Rollnick, M., Zwane, S., Staskun, M., Lotz, S., \& Gren, G. (2001). Improving pre-laboratory preparation of first year university chemistry students. International Journal of Science Education, 23(10), 1053-1071.

Russell, T., Harlen, W., \& Watt, D. (1989). Children's ideas about evaporation. International Journal of Science Education, 11(5), 556-576.

Sadler, T. D. (2009). Situated learning in science education: Socio scientific issues as contexts for practice. Studies in Science Education, 45(1), 1-42. http://dx.doi.org/10.1080/03057260802681839.

Şendur, G., Toprak, M., \& Pekmez, E. Ş. (2008). Buharlaşma ve kaynama konularındaki kavram yanılgılarının önlenmesinde analoji yönteminin etkisi. Ege Ĕ̆itim Dergisi, 9(2), 37-58.

Treagust, D. F. (1988). Development and use of diagnostic tests to evaluate students' misconceptions in science. International Journal of Science Education, 10(2), 159-169.

Treagust, D. F., \& Duit, R. (2008). Conceptual change: a discussion of theoretical, methodological and practical challenges for science education. Cultural Studies of Science Education, 3(2), 297-328. 
Treagust, D. F., \& Chandrasegaran, A. L. (2007). The Taiwan national science concept learning study in an international perspective. Journal of Science Education, 29(4), 391-403. http://dx.doi.org/10.1080/09500690601072790.

Tytler, T. (2000). A comparison of year 1 and year 6 students' conceptions of evaporation and condensation: dimensions of conceptual progression. International Journal of Science Education, 22(5), 447-467. DOI: 10.1080/095006900289723.

Uzuntiryaki, E., \& Geban, Ö. (2005). Effect of conceptual change approach accompanied with concept mapping on understanding of solution concepts. Instructional Science, 33(3), 1119. DOI:10.1007/s11251-005-2812-z

Ünal, S., \& Coştu, B. (2005). Problematic issue for students: Does it sink or float? Asia Pacific Forum on Science Learning and Teaching, 6(1), 1.

Valanides, N. (2000a). Primary students teachers' understanding of the process and effects of distillation. Chemistry Education Research and Practice in Europe, 1(3), 355-364.

Valanides, N. (2000b). Primary students teachers' understanding of the particulate nature of matter and its transformations during dissolving. Chemistry Education Research and Practice in Europe, 1(2), 249-262.

Voska, K. W., \& Heikkinen, H. W. (2000). Identification and analysis of student conception used to solve chemical equilibrium problems. Journal of Research in Science Teaching, 37(2), 160-176. 